Peter A. Kraus

\title{
3 Democracy's Challenge: Nordic Minority Politics in the European Context
}

\subsection{Democracy, the people and the paradox of sovereignty}

'The people' is a ubiquitous category both in modern constitutionalism and in the rhetoric of democratic politics. When it comes to defining what democracy is in a nutshell, the formula of 'government by the people' is recurrently used. At first sight, this sounds reasonable enough: In a polity that is supposed to meet democratic standards, the subjects of rule must also have a decisive voice in the process of ruling. Yet the apparent common sense may well hide one of the most intractable problems of democratic theory and practice, as Robert Dahl (1989: 116) would put it. The problem concerns the very identity of 'the people': Which are the specific features a given collectivity of persons must have to be able to claim that they constitute a people? If the people are supposed to be the ultimate source of democratic legitimacy, who can legitimately establish who the people are? By raising these questions we approach one of the big 'black hole' areas of political sociology and political science. Modern theories of democracy implicitly assume that 'a people' exists. In the language of modern constitutions, the assumption typically becomes a programmatic declaration. But what are the social and political realities underneath the constitutional claims of 'government by the people'?

I suspect that much of the concern many scholars and public intellectuals express when they are confronted with issues of identity politics may be caused by the uncomfortable feeling of getting close to the 'black hole'. An argument that can frequently be heard in this context is that instead of looking at our navels and discussing who we are we should rather focus on 'proper problems', i.e. problems that relate to the allocation of scarce resources. In contrast with this view, I will hold that defending an interest presupposes identity. After all, one of the main lessons to be drawn from the debate on multiculturalism and democracy of the last decades - a debate that seems far from being closed yet - is that democratic politics involves, by definition, identity politics. To ignore this would simply imply to keep one of the core domains of democratic rule insulated against the very logic of democracy. Here, the point not only lies in acknowledging the importance of input-oriented mechanisms of legitimation for democratic decision-making, as most political scientists would do. Input legitimation (Scharpf 1999: 6) is based on strong collective ties between the members of a community. These ties translate into a general consent which makes the outcome of an open political process acceptable to all community members. What identity politics now typically puts to the test are the very foundations of democratic input. For in many cases, raising identity issues means to question the legitimacy 
of the established 'self' that underlies the exercise of democratic self-determination. In more general terms, examining the link between identity and self-determination forces us to take on a theme that, despite its high relevance, has for a long time been neglected by mainstream social science, namely the study of the making, reproducing and transforming of political peoplehood (Smith 2003: 10). ${ }^{1}$

Jacobinism has obviously had a major impact on the modern political imagery when it comes to the notion of people-making. On the one hand, Jacobinism can be understood as the main ideological force sustaining the French Revolution and the republican legacy. In this regard, its principal characteristic is the implantation of a political culture of generality, where generality stands for the representation of the general will by public authorities in a way that creates an immediate link between the identity of the citizens and the 'grand national whole' epitomized by the state (Rosanvallon 2004: 13). On the other hand, the Jacobin phenomenon can be associated with the political dynamics of modernity in a broader sense, which makes the French experience comparable to other cases: From the angle adopted by Eisenstadt (1999: 72), Jacobinism is seen as a 'fundamentalism of modernity'. Accordingly, the main dividing line in modern politics would run between those who follow Jacobin orientations (be it with reactionary or with progressive intentions) and those attached to pluralist conceptions. From both perspectives, the tension between generality and particularity constitutes one of the central antinomies of modern democracy. Thus, what is at stake in the realm of identity politics ultimately is the very definition of what - or who - underlies the 'generality' that is to be democratically represented. Which identities can legitimately claim to be more general - and thereby democratic - than others? Who is who in democratic politics?

One can reasonably hold that the influence of Jacobinism on modern political thinking, which is still graspable today, when, for example, the virtues of 'thick' civic unity are praised against the dangers of multicultural fragmentation, is closely connected to the quasi mythical status that the French Revolution attained in the history of democracy and democratization. However, if we look at things more systematically, we may also assume that Jacobin views of democracy owe much of their enduring prominence to the possibility they offer for evading the 'black hole' which may emerge once we want to determine the identity of the people. In other words, the Jacobin approach offers an escape from the problems associated with what political theorists have called the 'paradox of sovereignty' or 'Rousseau's paradox'. What is the paradox about?

The concept of democratic sovereignty presupposes that there is a collective identity sustaining the polity which is conceived of as sovereign. Such an identity,

1 There is a huge body of work on nationalism. Yet political peoplehood does not necessarily require a national form, although in historical reality the making of peoples frequently overlapped with nation-building. 
however, can itself hardly be conceived of as an outcome of democratic decisionmaking. Democratic political structures do not emerge out of a historical vacuum, and the tribute we have to pay to history simply is that there is no democracy before democracy. To paraphrase the compelling observation made by Ivor Jennings (1956: 56), government by the people can only take place after somebody has decided who the people are. The roots of popular sovereignty are inextricably connected with a past which is pre-democratic, so that the people - the demos - appear on the political scene without genuine democratic credentials.

Thus, as Rousseau pointed out, those who want to establish a democratic polity ultimately have to rely on resources which themselves lack democratic legitimacy. ${ }^{2}$ Processes of establishing democratic rule have always involved inheriting a legacy made of asymmetries in the distribution of power. This legacy can only be tackled after democratic procedures have been introduced. In the moment of constituting a sovereign collective will, the people are on political grounds which are external to democracy. Now the Jacobin way of dealing with this situation and of circumventing the paradox of sovereignty has been to conflate the identity of the people with the identity of the state, constructing the 'grand national whole' Rosanvallon refers to in the French case. To cut a long and complex story short, the Jacobin approach consists in assuming that democratic sovereignty is ultimately embodied in the nation-state. The state represents an indivisible source of sovereignty, which is built on the uniform collective identity of the citizens.

The paradox of sovereignty thereby disappears to the extent that the Jacobin understanding of democracy converges with monist views of state power and citizenship: The nation-state becomes the ultimate source of political authority and the guarantor of uniform citizens' rights within a discrete territory, while state-based patterns of identification constitute the fabric of legitimate political rule. Against this background, one can indeed argue that the French model of linking peoplehood and statehood served well into the twentieth century as the standard pattern for envisaging political integration under conditions of modernity (Kymlicka 2007: 42). The idea of national sovereignty made for a strong and unique bond between 'the' people and 'their' state. Nonetheless, the fusion of Jacobin and monist principles never remained uncontested, not even in France. On the one hand, the specific way peoples are to be linked to states, so that criteria of democracy and justice are sufficiently met, has been a persistent matter of intense political conflicts. Since the French Revolution, the problems that derive from the paradox of sovereignty have been reverberating in still ongoing controversies on how the collectivities entitled to self-determination should be appropriately defined and redefined. Symptomatically,

2 The assessment can be found in Book II of The Social Contract (Section 7, 'The Legislator'). The paradox may seem even more paradoxical if we take into account that it was laid out by a philosopher who was bound to become a major source of inspiration for the Jacobins. 
up to now the quest for democracy can be associated with a continuous proliferation of potentially and factually eligible 'selves'. In the context of political development in Europe, it seems no coincidence that historical moments standing for a push towards democracy paved the way for the break-up of old, and the founding of new states. The wave of democratization at the end of World War I led to a significant increase of the number of European states. While one could count 28 of them around 1920, the figure had gone up to 39 around 1990, after the collapse of communism in the East. The more democracy, the higher the number of collective subjects who claim to have a right to self-determination, one may conclude. On the other hand, the basis of democratic sovereignty in a given political unit can be interpreted in pluralist ways, fostering the dispersion of power among groups and territories.

However, the imagery of the one and indivisible generality encapsulated within clear-cut borders remains quite powerful, as becomes evident if we look at political maps of the world, whose single components, each with its specific colour, are ultimately meant to represent the blending of peoplehood and statehood in an environment of 'United Nations'. The power visualized on these maps does not only have a symbolic character, but largely reflects the unequal access to resources used for defining collective identities in the politics of people-making. The dynamics of constructing the peoples who are to secure their claim on the political map thereby implies multiple forms of hegemonic categorization, as well as multiple attempts at overcoming its effects by articulating alternative identities. The political architecture of the people as the 'grand national whole' must rely on considerable institutional capacities to name collectivities, interpret histories and standardize languages. Power is required to strengthen the role of some collectivity, privilege its history and standardize its language at the expense of others. The application of the logic of Jacobinism to political integration entailed that the other was assimilated into the one and indivisible people under unequal terms. Thus, in the republican order established by Ataturk after the end of Ottoman rule, Kurds officially ceased to exist and were considered 'mountain Turks'. Following the same kind of pattern seven decades later, the constitution of post-communist Bulgaria banned ethnic and confessional parties, trying to put a political veil on the presence of a substantial portion of Turks among its population. So there were officially no Kurds in Turkey, as there should officially be no Turks in Bulgaria, to make sure that the picture of the one uniform people is not threatened by those who it does not represent. In more extreme cases, the attempts at imposing a hegemonic pattern of peoplehood against diverse identities entailed the massive use of physical violence and led to the expulsion or even elimination of entire segments of a state's original population. To depict the history of high modernity as a history of ethnic cleansing can therefore hardly be regarded as an exaggeration. That democracy has not always been a reliable safeguard against the prosecution of minorities in the name of the titular nations of modernizing states (Mann 2005) makes for a somewhat uncomfortable conclusion. 
Yet, it can't be denied that the fusion of national and democratic principles that both old and new states were eager to accomplish created a recurrent threat to the survival of minorities. The consolidation of nation-state sovereignty often led to the oppression of minorities for the sake of hegemonic integration. From the perspective of Europe's minorities, the legacy of the twentieth century is appalling. Even where state constitutions were supposed to guarantee minority protection, there was little official commitment to effectively implement the rights of minorities. In many cases, the de facto norm was anyway not to protect, but to get rid of minority groups, be it by assimilating them or by prompting their exodus. Accordingly, minorities can be seen both as the key witnesses and as the principal victims of the problematic character of the hegemonic link between democratic sovereignty and nation-state construction. As has been argued thus far, this is especially relevant if we wish to understand the manifold grievances members of 'old' minorities raise vis-à-vis the majority state. The labelling of groups such as the South Tyrolese, the Sámi or the Catalans as 'old' follows the intention of emphasizing their long and continuous presence in the areas they inhabit. Frequently, the groups in question were incorporated into the majority territory without their consent, and on that basis they often have a long historical record of struggles for attaining a sovereign or semi-sovereign status on their own grounds. Minority activism has certainly contributed to the erosion of the Jacobin paradigm of integration, which seems to have lost much of its former normative appeal all over Europe, as successive agreements on securing minority rights at the international level indicate. If we look at recent tendencies in international law and politics, what used to be the 'French model' nowadays rather looks like the 'French exception'. Nevertheless, we should be cautious before announcing the decline of the once hegemonic approach to people-making.

While we may have witnessed some progress regarding the situation of minority groups of 'endogenous' origin in Western democracies, it is more difficult to make a general assessment concerning 'new' minorities, that is minorities constituted by groups with an immigrant background, who at present make for a substantial portion of Europe's population. Concerning their status, it may be too hasty a move to maintain that there has been a general retreat from multiculturalism and a return to assimilation as the dominant approach in the liberal democracies of the West, as some observers have done (Brubaker 2003). However, over the last few years several Western European countries have indeed emphasized their intention to uphold wellestablished majority identities before the cultural changes brought by immigration. Thus, admission to citizenship is made contingent upon passing tests which ultimately scrutinize the affinities an applicant has developed towards what one might call the host society's 'official image'. The controversies stirred by such measures are not caused because of their declared intention to foster the dynamics of civic integration in contexts marked by an increasing cultural heterogeneity, but by the re-affirmation of hegemonic patterns of people-making they apparently intend. 


\subsection{The challenge of minorities}

The concept of minority typically refers to groups who find themselves in a position of relative subordination in a given societal context, as they lack the structural capacity for generalizing key features of their group identity with regard to the dominant group. Sheer numerical inferiority may be the main reason for such a situation, but numbers tend to connect to other factors in manifold ways. At the same time, these other factors point to a cultural profile, based on ethnicity, religion or language, which is distinctive of the minority. Hence, in contrast to political minority options, which can potentially be adopted by an ever growing number of people and ultimately become majoritarian, attachments to a particular cultural identity tend to be of a more sticky kind, and less susceptible to deliberate choices. While all kinds of human civilization seem to have produced their minorities, the minority status gains particular salience with the formation of modern nation-states. This is so because of the great weight a shared cultural identity attains for political integration in the age of nationalism (Gellner 1997). By setting the standards that defined the identity of its citizens, the modern state tended to discard those identity patterns that were peripheral or even undesirable to the officialized self-understanding of the nation: Minorities are the product of institutional cultural politics. As I have argued previously, the logic of minority conflicts is inherent to the architecture of the nation-state. However, the conflicts and their outcome still reflect the contingency of politics. Accordingly, one must keep in mind that 'minority' and 'majority' are relational categories. The parameters characterizing this relation reflect the use of power, as well as the unequal access to power resources that different actors have (Kraus 1996: 370). How minorities interact with dominant groups, and how their position worsens or improves in this interaction, depends on political contexts which are subject to change.

Notwithstanding the importance of contextual factors, there are a few general aspects that we may take into account to attain a better understanding of majorityminority relations. One first aspect has already been mentioned: It is the distinction between 'old' and 'new' minorities. Old minorities are often also categorized as national minorities, in contrast with the ethnic minorities formed by immigrant groups (Kymlicka 1995: 11-15). In many respects, the central implication of drawing this distinction is to assign the claims of the respective type of minority a different normative status. National minorities want to maintain their specific group identity within a historical homeland, which they see as the basis for articulating claims for autonomy and justifying the objective of setting up solid institutional structures conducive to their collective empowerment. Ethnic minorities obviously lack such a homeland in the host country. In general, their claims do not primarily focus on preserving or re-establishing a particular institutional status, but rather aim at achieving their incorporation in the receiving society under conditions of equality.

The second aspect overlaps to some extent with the first one, as national minorities are in most cases territorially concentrated minorities. Territorial concentration works 
in favour of minority mobilization and makes it easier to introduce provisions that give minorities extensive rights to self-government. On the other hand, it also has to be noted that disposing of an 'own' territory is a crucial asset for collectivities who want to accentuate their potential for institutional completeness before the majority state, thereby moving from autonomy towards independence. It is this constellation which can dramatically exacerbate the implications of the paradox of sovereignty by leading to a conflict over a minority's right to secede.

A third aspect which may play a role in structuring the frame of ethno-national politics is whether a minority can rely on some type of external protection (Offe 1994: 145). This is especially relevant in those cases where the protection comes from a neighbouring state that identifies ethnic kin-groups abroad as part of a larger national community, thereby fuelling conflicts over the legitimacy of territorial settlements in ethno-nationally mixed areas. The intertwining of intra-state and inter-state conflict dimensions may further complicate dealing with minority issues, as sovereignty has to be negotiated both between groups and between states. For a long time, and up to the present, dealing with the national question in Eastern Europe has been marked by this syndrome.

External protection, territoriality and nationality are variables delineating potentials that minority groups may use for their mobilization. Assessing such potentials will possibly help us to get a better understanding of the relatively strong position a group such as the already mentioned South Tyrolese has for putting forward its demands if we compare it to, say, members of the Kurdish diaspora spread across Western Europe. In one case, we have the typical example of a national minority concentrated in a borderland area. The support it received from the Austrian side after World War II was clearly functional for achieving ample autonomy rights vis-à-vis the Italian state. In the other case, the resources for exerting strong political pressure are basically lacking: Thus, activists trying to mobilize for the Kurdish cause in German cities, for example, do not receive any institutional support from the side of Turkey, where the bulk of Kurdish immigration to Germany stems from. As the Kurds in Germany lack political control over a homeland 'of their own', German authorities are generally reluctant to classify them as an independent ethnic group, let alone to recognize them as a nationality.

However, to what extent potentials are activated follows no automatic logic, but is, again, a question of political contingency, as is exemplified by the case of the Swedish speaking Finns, who may well be considered a 'strong' minority, although - if we leave aside the case of Åland - they lack both external protection and a clear-cut territorial basis. Neither have they been assigned nationality status. Hence, an assessment of the impact of 'objective' resource potentials will not render an analysis of the deeper context of minority politics superfluous. It is this very context that we need to look at if we want to grasp the manifold ways power frames majority-minority relations. Still, regardless of the ultimately crucial significance of contextual factors, there are two major challenges of a general character involved in any attempt at tackling minority 
issues under democratic conditions. They are intrinsically connected to our point of departure, namely the 'black hole' in which sovereignty has to be constituted. Hence, both challenges relate to the problem of giving a satisfactory answer to the question of who the (legitimate) people are, although the question has to be confronted from different perspectives in each case.

The first challenge refers to the threat minority demands may represent for holding together nation-states as the key units for collective decision-making in the modern world. It can be called an 'external' challenge, since it results from the lack of legitimacy minorities attribute to the majority state for dealing with their affairs. As I have argued, most states have tried to prevent having to take up this challenge by striving for the cultural homogenization of their population, turning it into one people. From a present-day perspective, it seems out of question that the normative cost of linking the goal of democratic integration to assimilationist policies is excessively high, and that majority states have the obligation to respect the identity of minority cultures. It must also be acknowledged, however, that the problems the paradox of sovereignty bears when it comes to constituting a legitimate type of demos will hardly be addressed in appropriate ways by advocating an endless multiplication of minority-controlled political units. To put it in more figurative terms: We will not evade the darkness of the one black hole of sovereignty by simply creating a great many black holes. Thus, the external challenge ultimately begs the question of how to define a proper balance between unity and diversity. As has been argued here, neither negation nor homogenization is a justifiable response to diversity. Diversity requires accommodation. At the same time, accommodation will be difficult to achieve if the foundations of a common polity are persistently and vehemently questioned by minority groups. It also has to be said, though, that majorities are often inclined to conceive of accommodation as a one-sided exercise. The 'other' represented by the minority is then only recognized as some kind of appendix to the still dominant 'grand national whole'. Otherness is only tolerated as long as it can be kept outside the core areas of sovereignty, so that being a minority ultimately remains linked to a status of subordination, be it only in the literal sense of remaining exposed to the categorical authority of a superior unit. Accordingly, the standard approach to dealing with minority issues adopted in institutional contexts determined by nation-state prerogatives is based on a politics of unequal recognition, which assigns minorities a 'special status', while it takes the majority identity for granted.

The second challenge concerns the way minorities represent and articulate themselves. In this sense, we might speak of an 'internal' challenge, which points at the very foundations of minority identities. The paradoxical character of the political dynamics of people-making becomes patent here as well, as the institutionalization of a minority identity often entails an 'isomorphic' reproduction of hegemonic standards. The spaces which are opened to enable minorities to develop a counterhegemonic discourse and challenge patterns of domination remain thereby subject to the very logic they supposedly question. At any rate, this is a criticism that minorities 
in control of autonomous institutional realms are often exposed to: While pretending to defy the dominant group's power of categorization, they would apply all too rigid categorization strategies when determining their own 'self'. In a similar vein, minority institutions - political bodies, educational organs, cultural academies or minority-run media - are often portrayed in parodist ways, as if they were obsessively devoted to reproducing the dominant patterns of identity attribution on a minor scale. In consequence, minorities are often accused of being unable to transcend the essentialist politics they once had been themselves victims of. Minority groups are thus confronted with an expectation that representatives of dominant cultures rarely had to care about: to articulate their identities in a reflective and non-essentialist way. ${ }^{3}$ It is certainly justified to judge contemporary identity politics by other normative standards than those that were in place during the high time of nationalism. Yet, by doing so, one should also be careful not to incur in an unequal blaming, which is only the reverse side of unequal recognition. The practices of categorization we may find problematic in minority discourses respond to imperatives that continue occupying a central place in the language of modern politics and thereby push those involved in minority politics towards conceiving of identities as having an essential quality. Ultimately, the 'nationalizing' and 'essentializing' elements detectable in the mobilization rhetoric of an indigenous minority such as the Sámi must not be disconnected from the massive impact of Norwegian, Swedish, Finnish and Russian state policies when it comes to setting the terms of discursive exchange in majorityminority relations in Europe's far North.

Both the external and the internal challenge are inherent features of minority politics and have to be tackled in some form by disentangling the puzzles of sovereignty and disaggregating 'the' people into different yet complementary collectivities. Let me stress once again, however, how critically significant contextual factors are for getting an appropriate understanding of what is at stake in any specific minority mobilization. Only the sound analysis of context will allow us to grasp whether the identity claims of ethnic groups and nationalities work against or reinforce the hegemonic logic in the politics of people-making.

\subsection{Minority politics in the Nordic context}

Nordic countries are frequently described as being remarkably homogeneous by comparative European standards. This homogeneity is generally understood as an absence of pronounced cultural or religious differentiation. From such an angle, cultural homogeneity is considered a key background element for understanding the

3 The critique of the essentializing view has been of central concern in the debate on the formation of social and cultural identities triggered by post-structuralism; see, for instance, Kristeva 1991. 
situation of minority groups in Northern Europe (Allardt 1981). In addition, the high level of cultural homogeneity would explain the low intensity of ethnic conflicts in contrast with other areas of Europe in the age of nationalism.

Moreover, cultural homogeneity can be interpreted as a factor which fostered the development of strong and wide-ranging welfare state structures in the Scandinavian region. Such a view is based on the observation that ethno-linguistic differentiation tends to have negative effects on the level of organisation of labour in a country. Low levels of labour organization in turn, tend to be negatively correlated with the volume of social spending (Stephens 1979). Against this background, the controversial assumption that cultural diversity is bad for social equality has been voiced in an upcoming and intensifying debate on the relationship between multiculturalism policies and the welfare state. ${ }^{4}$

The concept of homogeneity - of a historically entrenched homogeneity, one might want to add - seems to be a good starting point for assessing minority politics and the impact of immigration on established identities in the North. In this respect, I think that there are two aspects that are highly relevant for a critical reflection on the dominant approach to minority issues in the area. In the first place, we should be careful not to take homogeneity as something given, as the self-evident basis for the processes of social and political integration that sustained the blending of peoplehood in statehood in countries such as Sweden or Finland. We can certainly accept the argument that the early amalgamation of religious and political power structures brought about by the establishment of state churches made for a less arduous path to nation-building in the North than in the Continent's South, marked by a long-lasting division of religious and secular authorities (Rokkan 1999). However, such an argument does not necessarily imply that Nordic diversity patterns smoothly dissolved in the process of nation-state construction. To use the powerful image of the folkhem, coined by Sweden's Social Democrats: We should not assume that the people to be given their home were in the political picture from the beginning, happily waiting to get what they deserved as good citizens. Rather, these very people have to be conceived of to a substantial extent as a collectivity tailored by state institutions. Accordingly, what we perceive today as a strikingly high level of homogeneity would have to be seen as the product of a successful homogenization. To be sure, the historical rationale of homogenization varies from case to case. In Sweden, it may be linked to deliberate attempts by reformist state elites to create a thick bond between the citizens and 'their' polity, in a way that has some resemblance with the patterns of the French republican model. In Finland, it may rather be related to a particular combination of internal and external pressures in the political context of a young state in which social and political structures of a Nordic type overlapped

4 The volume edited by Banting and Kymlicka (2006) contains a first critical assessment of this debate. 
with an East European path to national revival (Alapuro 1988). I am clearly not pretending to offer any conclusive view of the dynamics of people-making in the North here. Nor is it my intention to replace the story of the folkhem with a narrative that focuses exclusively on the homogenizing thrust of integration. I simply want to emphasize that homogeneity should not be taken for granted as a historical given, but be related to shifting political constellations that make it more or less effective. One could look at the city of Helsinki, for instance, that some 100 years ago was a much more diverse place, characterized by minority experiences and intercultural exchanges of multiple kinds, than it is today.

The second aspect I would like to bring into focus when sketching out an approach to minority politics in the North is the thorny relationship between equality and homogeneity. The Nordic welfare state tradition has created robust links between national identity and social citizenship, links that found a compact expression in the Swedish concept of folkhemmet. Now, the key question in the context of our discussion here is to what extent the construction of the people's home went hand in hand with the tendency to conceive of social equality in terms of cultural homogeneity. At the core of the idea of social citizenship is the notion that a minimum of protection and well-being is required to guarantee individual autonomy and enable men and women to make meaningful use of their civil and political rights. Since the comparative analysis of welfare regimes presented by Esping-Andersen (1990), it has become all but a commonplace in the social sciences that universalism is one of the most characteristic features of welfare policies in Scandinavia. At its most elementary level, this universalism implies that basic social entitlements have to be guaranteed to all citizens regardless of their status or class. I have certainly no intention to question this noble perspective and the emphasis it places on the egalitarian dimension of citizenship. What we perhaps have to scrutinize more thoroughly, however, are the patterns of collective identity underneath the claims for universalism of the folkhem: Which kind of who is constitutive of the Scandinavian welfare universe? The Nordic welfare architecture is based on a strong commitment to achieving the social inclusion of all citizens. Such a commitment may involve a relatively hesitant public attitude towards admitting newcomers, as welfare states are still nation-states and as the universal entitlements they guarantee are controlled by national authorities, and meant to benefit nationals in the first place. For this reason, Jytte Klausen (1995: 246) takes a sceptical stance towards the ethos of universalism that is supposed to sustain social citizenship in Scandinavia: 'It can in fact be argued that the Scandinavian welfare states are as much examples of closure and exclusion as they are examples of welfare state inclusion. Which feature predominates depends upon one's vantage point, particularly whether one is a citizen or an alien.'

Klausen opens up an interesting angle of analysis, which deserves further elaboration. In this context, my assumption is that the limitation of universalism to those inside the folkhem may only be one part of the story, an important one, 
to be sure. However, what seems even more relevant for the argumentation I have been sketching out on these pages is the possible trade-off between inclusion in the people's home and the recognition of diversity. To what extent have universalist intentions been conflated with homogenizing practices? This is obviously a topic of crucial concern whenever we talk about minority politics. What ultimately is at stake in tackling it is whether cultural assimilation is the price we have to be prepared to pay to avoid social exclusion. For decades, the rhetoric of inclusion has been used to force indigenous peoples and minority groups to acquire a cognitive repertoire that conformed to the majority identity. Accordingly, the degree of inclusion of a citizen of Sámi or Roma origin in, say, Swedish society largely depended on his or her disposition to leave behind his or her culture of origin and become part of the presumedly universal community of industrial workers, small farmers and civil servants represented by the welfare state. In a similar way, the predominant approach to (political and social) citizenship - kansalaisuus - in Finland appears to be inextricably intermingled with an understanding of nationality - kansallisuus - with thick cultural connotations that makes it difficult to accept immigrants as equal as long as they remain different (Lepola 2000). Yet, if democratic citizenship is about equality as a means to empowerment and freedom, be it at the individual or at the collective level, there is no justifiable reason to interpret the concept of social inclusion in assimilationist terms.

Thus, the many positive attributes that the nation-state has attained in the North as a guarantor of social cohesion might appear in a somewhat darker light due to a long-running tendency to conflate inclusion and assimilation. In Northern Europe, the civic republicanism of the French model was apparently enriched with important social elements, but this did not imply a rupture with the Jacobin approach to integration. Simplifying things, we could say that in the North the black hole of sovereignty was filled with the discourse on social welfare, but that addressing the paradox of sovereignty in this way did not substantially improve the fate of minorities exposed to the hegemonic logic of nation-state construction.

Let me end with an observation that brings together the two aspects which I have highlighted for the purpose of contextualizing minority politics and ethnic relations in the Nordic countries. The central role played by nation-state institutions in the field of securing social cohesion becomes patent even in those spaces that have successively been opened up during the last decades to recognize the existence of diverse identities under a common political roof. On the one hand, provisions that shall give different minority groups varying degrees of cultural autonomy are typically introduced and implemented following a top-down approach. The legitimacy that Sámi identity claims may have in Finland, to mention one concrete example, seems to depend by and large on how these claims adjust to the operation rules of Finnish public authorities. In a similar way, when looking at how public boards that shall promote the effective integration of immigrant groups in their local environments have been established in Nordic democracies, one may wonder 
what the main priority is: Is it the due representation of newcomers, or is it possibly rather the preventive co-optation of minorities before they begin mobilizing themselves? If we want to take the challenge of minorities seriously, we need to develop criteria that allow us to distinguish between paternalizing and emancipatory forms of recognition. Furthermore, we have to be aware of the great risk that a politics of recognition orchestrated from above, regardless of all good intentions, just keeps applying the homogenizing logic, that structured the dominant national identity, to minority groups so that they conform to definitive standards that may be convenient to state bureaucracies, yet fail to meet the challenge of reconciling equality and diversity.

\section{References}

Alapuro, R. 1988. State and Revolution in Finland. Berkeley: University of California Press.

Allardt, E. 1981. 'Ethnic Minorities'. In E. Allardt, N. Andrén, E. J. Friis et al., eds. Nordic Democracy: Ideas, Issues, and Institutions in Politics, Economy, Education, Social and Cultural Affairs of Denmark, Finland, Iceland, Norway, and Sweden. Copenhagen: Det danske Selskab, 627-49.

Banting, K. and Kymlicka, W., eds., 2006. Multiculturalism and the Welfare State: Recognition and Redistribution in Contemporary Democracies. Oxford University Press.

Brubaker, R. 2003. 'The Return of Assimilation? Changing Perspectives on Immigration and its Sequels in France, Germany, and the United States'. In C. Joppke and E. Morawska, eds., Toward Assimilation and Citizenship: Immigrants in Liberal Nation-States. Houndmills: Palgrave Macmillan, 39-58.

Dahl, R. A. 1989. Democracy and Its Critics. New Haven: Yale University Press.

Eisenstadt, S. N. 1999. Fundamentalism, Sectarianism, and Revolution: The Jacobin Dimension of Modernity. Cambridge University Press.

Esping-Andersen, G. 1990. The Three Worlds of Welfare Capitalism. Cambridge: Polity Press.

Gellner, E. 1997. Nationalism. London: Weidenfeld \& Nicolson.

Jennings, I. 1956. The Approach to Self-Government. Cambridge University Press.

Klausen, J. 1995. 'Social Rights Advocacy and State Building: T. H. Marshall in the Hands of Social Reformers'. World Politics 47: 244-67.

Kraus, P. A. 1996. 'Minderheiten'. In D. Nohlen, P. Waldmann and K. Ziemer, eds., Lexikon der Politik. Band 4. Die östlichen und südlichen Länder. München: Beck, 369-79.

Kristeva, J. 1991. Strangers to Ourselves. New York: Harvester Wheatsheaf.

Kymlicka, W. 1995. Multicultural Citizenship. Oxford University Press.

Kymlicka, W. 2007. Multicultural Odysseys: Navigating the New International Politics of Diversity. Oxford University Press.

Lepola, 0. 2000. Ulkomaalaisesta suomenmaalaiseksi: Monikulttuurisuus, kansalaisuus ja suomalaisuus 1990-luvun maahanmuuttopoliittisessa keskustelussa. Helsinki: Suomalaisen Kirjallisuuden Seura.

Mann, M. 2005. The Dark Side of Democracy: Explaining Ethnic Cleansing. Cambridge University Press.

Offe, C. 1994. Der Tunnel am Ende des Lichts. Frankfurt a. M.: Campus.

Rokkan, S. 1999. State Formation, Nation-Building, and Mass Politics in Europe. Oxford University Press.

Rosanvallon, P. 2004. Le modèle politique français. Paris: Seuil. 
Scharpf, F. W. 1999. Governing in Europe: Effective and Democratic? Oxford University Press. Smith, R. M. 2003. Stories of Peoplehood: The Politics and Morals of Political Membership. Cambridge University Press.

Stephens, J. D. 1979. The Transition from Capitalism to Socialism. Urbana: University of Illinois Press. 